\title{
Inventing Interfaces
}

\author{
Camillo's Memory Theater and the Renaissance of \\ Human-Computer Interaction
}

\author{
Peter Matussek
}

He called upon future generations of "wise men" (11) to fulfill what he had left unfinished. Throughout the last two decades of his life, Giulio Camillo (1480?1544) worked on his legendary Theatro, a room-size wooden construction in the style of the Vitruvian theater that supposedly contained "the Ideas of everything Celestial and Inferior" in symbolic form, thus enabling its visitor to memorize the entire cosmos. Although, or rather because, his "fabrica" had been seen by only a few people-the king of France and the Dutch statesman Viglius among themit attracted the curiosity of his contemporaries. During an illness three months before his death, Camillo felt that it was time to consider his project's afterlife and to convince skeptics that he had not made empty promises. From his bed, he dictated to his close friend Girolamo Muzio a treatise in which he described the architecture and the intended contents of his masterpiece. Six years later, this treatise was published under the title L'idea del theatro. Formulated in the future tense, it expresses the confidence that someday a genius like him will be able to finish the labor, guided by his tutorial. Certainly, Camillo had not expected that it would take centuries before his theater's construction plan would be revisited.

After Camillo's time, the project fell almost completely into oblivion. It was not until exactly 400 years after the publication of L'idea del theatro that Ernst Gombrich-then senior research lecturer at the Warburg Institute-took the little booklet from the library shelves, handed it over to his colleague Frances Yates, and asked her to read it. ${ }^{2}$ Yates soon realized that an enormous amount of further reading would be necessary to grasp what Camillo's short treatise was about. It took sixteen years of intensive study before she could publish her findings in her book The Art of Memory (1966), which placed Camillo's work within the context of the 
mnemonic tradition from Aristotle to Shakespeare. The Art of Memory emerged as one of the most influential nonfiction books of the twentieth century. ${ }^{3}$ It found a reception far beyond the community of scholars of the history of ideas (who had largely rejected it). The two chapters on Giulio Camillo, in particular, attracted readers from a great variety of fields: artists, architects, and-with increasing frequency-media scholars, who deal with issues of information visualization, interface design, and human-computer interaction (HCI). This comeback of a fivehundred-year-old, enigmatic, premodern, cosmological concept in the context of digital technology is all the more astonishing given that Yates did not emphasize its rational, encyclopedic aspects, but rather (to the disapproval of many historians) its rootedness in Hermeticism and magic. She thus did not suggest any analogies between Camillo's intentions and computer technology. ${ }^{4}$ This begs the question: Why was it the digital age, of all ages, that turned out to be the one to perceive itself as the future that Camillo addressed? The question is all the more pressing, given that the book that paved the way for this reception emphasized precisely those aspects of the past that seem to stand in contradiction to the instrumental reason of computerized modernity.

To venture an answer, we must first examine Camillo's Idea within the context of his time and find out what about his Theatro makes it so unique among the vast Theatrum literature from the sixteenth to the eighteenth centuries. Second, we need to understand why the rediscovery of the text through Yates's work had such an enormous effect. Third, we must examine the correspondences between Camillo's invention technique and the invention of human-computer interfaces in order to evaluate the prospects of this correspondence for the future.

\section{CAMILLO'S INVENTION}

Nothing is left of Camillo's theater, of which he had reportedly "finished" a first version during his stay in Sebastiano Sauli's villa near Genoa in $1525 .{ }^{5}$ Even the contemporary reports about it-his own and those of the very few visitors who were allowed to see it-remain peculiarly vague. If he really had already finished the project, however, why would he have spent the rest of his life searching for patrons to finance it? After having persuaded Francis I to give him the generous sum of 500 ducats, Camillo often explained his secretiveness about the theater's interior by claiming that the king had provided his support on the condition that Camillo not talk about the project to anyone else. ${ }^{6}$ This declaration enhanced the aura of mystery among his devotees, who even called him "divine,"7 but it drew skepticism from others. Solidly on Camillo's side were artists such as Titian and Francesco Salviati, both of whom were supposed to contribute paintings to the theater, ${ }^{8}$ whereas contemporary scholars were divided in their judgments. Pietro Bembo, Johannes Sturm, and Johannes Calvin, for instance, sympathized with Camillo; Paolo Giovo, Étienne Dolet, and others regarded him "as a quack and a 
pretender." 9 Accordingly, they expressed suspicion that Camillo's agreement with the king was "a scam." ${ }^{10}$ Erasmus, at first friendly with Camillo, later became wary of him when he realized that Camillo opposed his Ciceronianus. ${ }^{11}$

It is important to keep this uneven contemporary reception in mind when evaluating the sole surviving eyewitness account of the mysterious theater's interior. It stems from a letter written by Viglius Zuichemus, who was a close friend of Erasmus. The latter harbored doubts about Camillo. When Zuichemus stayed in Venice in 1532, Erasmus asked him for a report on the project. In language that expresses astonishment and alienation at once, Viglius wrote:

The work is of wood, marked with many images, and full of little boxes; there are various orders and grades in it. He gives a place to each individual figure and ornament, and he showed me such a mass of papers that, though I always heard that Cicero was the fountain of richest eloquence, scarcely would I have thought that one author could contain so much or that so many volumes could be pieced together out of his writings. ... He calls this theatre of his by many names, saying now that it is a built or constructed mind and soul, and now that it is a windowed one. He pretends that all things that the human mind can conceive and which we cannot see with the corporeal eye, after being collected together by diligent meditation may be expressed by certain corporeal signs in such a way that the beholder may at once perceive with his eyes everything that is otherwise hidden in the depths of the human mind. And it is because of this corporeal looking that he calls it a theatre. ${ }^{12}$

What Viglius points out here are the oddities of someone who adheres to oldfashioned Ciceronianism and to a concept of memorization that seems so bizarre to him that he does not even try to understand it. In his letter, he admits frankly that he expressed admiration for Camillo only to hear him speak and thus convict himself of quackery: "When I asked him concerning the meaning of the work, its plan and results - speaking religiously and as though stupefied by the miraculousness of the thing-he threw before me some papers, and recited them so that he expressed the numbers, clauses, and all the artifices of the Italian style, yet slightly unevenly because of the impediment in his speech." ${ }_{13}$

Like every scholar of his time, Viglius was, of course, well acquainted with the ars memoria as part of the basic education in rhetoric. With origins in ancient Greece, the teaching of rhetoric was divided during the Hellenistic period into five categories, or canons: inventio, dispositio, elocutio or pronuntiatio, memoria, and actio. The proper knowledge of these became obligatory for every student as an essential part of the trivium, the lower section of the septem artes liberales. And the standard books through which it was taught were Cicero's De Oratore, the pseudoCiceronian Rhetorica ad Herennium, and Quintilian's Institutionis Oratoriae. All three begin their explanation of the "art of memory" with a legend about the Greek lyricist Simonides, who supposedly was the only survivor of a banquet in a palace that collapsed; he was able to identify the bodies because he remembered who had been where. The contemporary reports on Camillo's theater contain some hints 
that it would function as such a memory palace. During his trip to France in 1530, for instance, he is said to have demonstrated his method to Claudio Rangone, helping him to easily memorize the Miserere in Latin and the Nunc Dimittis in the vernacular. ${ }^{14}$ But it would be absurd to assume that the function of miraculous theater, of which Camillo made such a fuss, would amount to nothing more than learning short texts by heart. To understand its purpose better, we must take a closer look at Camillo's treatise, Lidea del theatro, which he dictated to his friend Muzio shortly before his death.

At first sight, the booklet of 86 pages $^{15}$ seems to lead us even further into the dark. It starts by declaring that the "wisest writers always have had the habit of protecting in their writings the secrets of God with dark veils" ( 7 ). Therefore, Camillo claims, "we use symbols in our own affairs, as signifying those things that should not be desecrated" (9). And what follows is full of enigmatic references to a syncretistic mixture of biblical, Homeric, Orphic, Zoroastrian, Platonic, Aristotelian, gnosticist, neo-Platonist, Hermetic, and cabalistic scriptures. Thus, one might argue that Camillo treats his prospective readers in the same way he treated his contemporaries: leaving clarifications for a tomorrow that never comes. In his dedication to the treatise, the editor, Lodovico Domenichi, concedes that the theater Camillo describes has not progressed beyond the stage of a project; he expresses the "hope that many of those who, for whatever cause, either envy or ignorance, said that M. Giulio Camillo had promised too much, by reading this Idea will know that for him it was as easy to fulfill the promise, as he was ready to make it" (4). This explains why the descriptions of the contents of the theater are written in the future tense, but not what the theater was ultimately supposed to look like.

If, unlike Viglius, we attempt to take Camillo's effusions seriously, we can find plausibility in them. First of all, he is very clear in describing the architecture of the construction: a Vitruvian-style amphitheater with a circle of seven tiers for the audience, each divided in turn into seven sections. On each of these 49 seats are placed images. In this respect, the theater fulfills the requirements of the Roman ars memoria, which is based on the principle of loci et imagines-i.e., placing images in a well-structured building as reminders of the things one wants to memorize. Camillo also seems to stay within the framework of the ancient ars when he states: "Therefore, our great labor has been of finding an order in these seven measures, which is capacious, sufficient, clear and which will always stimulate the mind and jog the memory" (11). At first glance, this is just referring to the recommendation of the Roman rhetoricians to use imagines agentes, i.e., images that are pregnant with some feature that activates the mind, so that they stick in one's memory. Even the wording about the effect on the memorizer's mind is identical (Camillo: percossa; Cicero: percutere). ${ }^{16}$ However, we must not overlook the difference in the catalyst for this activation of the memory: The Roman rhetoricians ascribe it to the images themselves, whereas for Camillo it is their order that should stimulate the 
mind. Such an order can only be thought of as being dynamic. And its intended effect to "jog the memory" - or, as Camillo also says, "to awaken memory" (62) does not align with the model ascribed to Simonides of a fixed seating order of bodies. What Camillo has in mind is a performative turn of the ars memoria. To that end, Camillo draws on the Lullistic ars combinatoria, which tries to overcome the necessarily limited representation of things in a static topography with a flexible system that could generate any idea by permutation of their elements. It was precisely this idea of performing logical operations in an analogy to acts on a stage that led Camillo to call his construction a "theater." How did it function? To clarify this further, we need to examine Camillo's Lidea del theatro within the context of the scientific literature of the Early Modern Age.

Among the eight hundred or so books that appeared between the fourteenth and eighteenth centuries with "theatrum" or something semantically similar in the title, Camillo's is the fourth. ${ }^{17}$ The three that appeared before L'idea del theatroand nearly all of the ones that came after (the few exceptions will be discussed below)-use the term only to indicate that they intended to provide an overview of objects of knowledge of any kind (instruments, proverbs, cities, human passions, appearances of devils, professions, cruelties, evil women, etc.) by arranging them in a manner consistent with a mode of presentation established by the Vitruvianstyle theaters of the Renaissance: namely, unlike in the Medieval liturgical performances, the public was now separated from the elevated stage and thus excluded from participation. ${ }^{18}$

The contrast with Camillo's theater could not be greater. What makes his conception stand out against the theatrum literature of his time and, even more starkly, of future centuries, is above all his inversion of the architectural functionality of the Renaissance theater. By placing the visitor on the stage and the memory images on the surrounding tiers usually reserved for the audience, Camillo turns the user of his device into an actor. This actor's mind is stimulated by the arrangement of the images in an order that prompts him to combine their meanings and perform his own recollection activities. The vast difference between this memory model and the mainstream is already indicated by the title page of the first edition of his book (figure 3.1).

Designed posthumously, but undoubtedly aligned with Camillo's intentions, the page depicts, on the right, Orpheus with his lyre. Son of the Muse Calliope and thus grandson of Mnemosyne (the goddess of memory), Orpheus stands for remembrance through music as a time-based art, in contrast to the spatial understanding of memory in the ars memoria. Also time-based, and equally opposed to the memory concept of storage, is the story to which the Orpheus illustration alludes in combination with the figure on the left, Persephone. ${ }^{19}$ It points to the narration of Orpheus's descent to the underworld, where he softened the hearts of Hades and Persephone so that they allowed him to bring his beloved Euridice back alive-under the condition that he not turn back to look at her on their way 


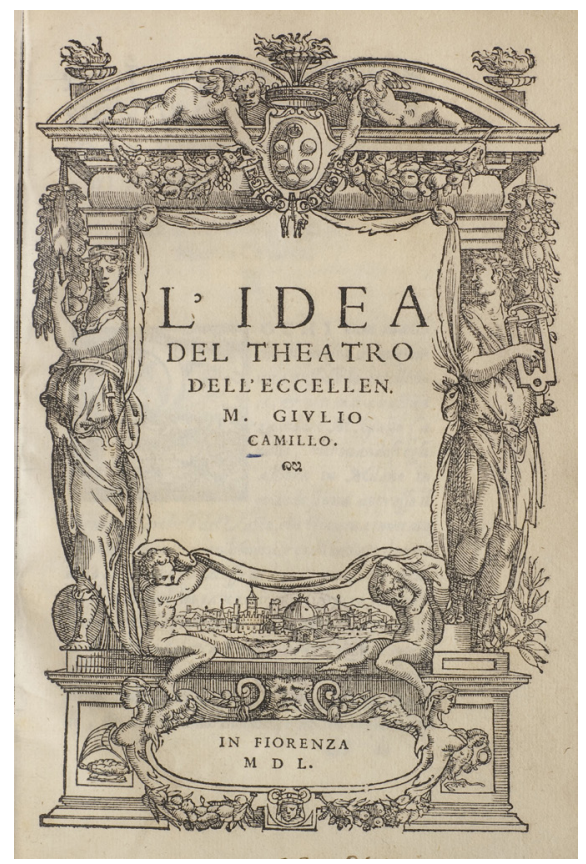

FIGURE 3.1. Title page of Giulio Camillo, L'idea del theatro (Florence: Torrentino, 1550) (c) Herzog August Bibliothek Wolfenbüttel. http://diglib.hab.de/drucke/qun-139-2-1s/start. htm?image $=00003$

out. This condition, as narrated by Ovid, the well-known source of the mythological knowledge of Camillo's time, gives a clear indication that true remembrance may not rely on fixed images: Orpheus, Ovid writes, may not look at Euridice with the desire of holding fast her visual appearance. ${ }^{20}$ As we know, Orpheus could not accomplish the task of relying solely on his episodic memory ${ }^{21}$ of Eurydice; by trying to verify her presence physically, he lost her forever. Thus, the message of the title illustration of L'idea del theatro can be seen as a rejection of the memory concepts of all those books of the Early Modern Age that take the theater model as an exposition space for the presentation of knowledge objects and whose frontispieces are depicted accordingly.22

The most striking characteristic that makes Camillo's treatise unique is, of course, that it takes the term "theater" not just metaphorically but literally as something to be built. Let us then enter it now in our imagination and try to figure out how it works. Standing on the stage and looking at the audience tiers, we see images, arranged in seven circles, divided in seven sectors (figure 3.2). As we already know, our task is not simply to keep the places of the images in mind, but also to understand the dynamics of their architectural order. This order of seven by seven is meaningful in itself: The seven sectors are to be viewed as the seven pil- 


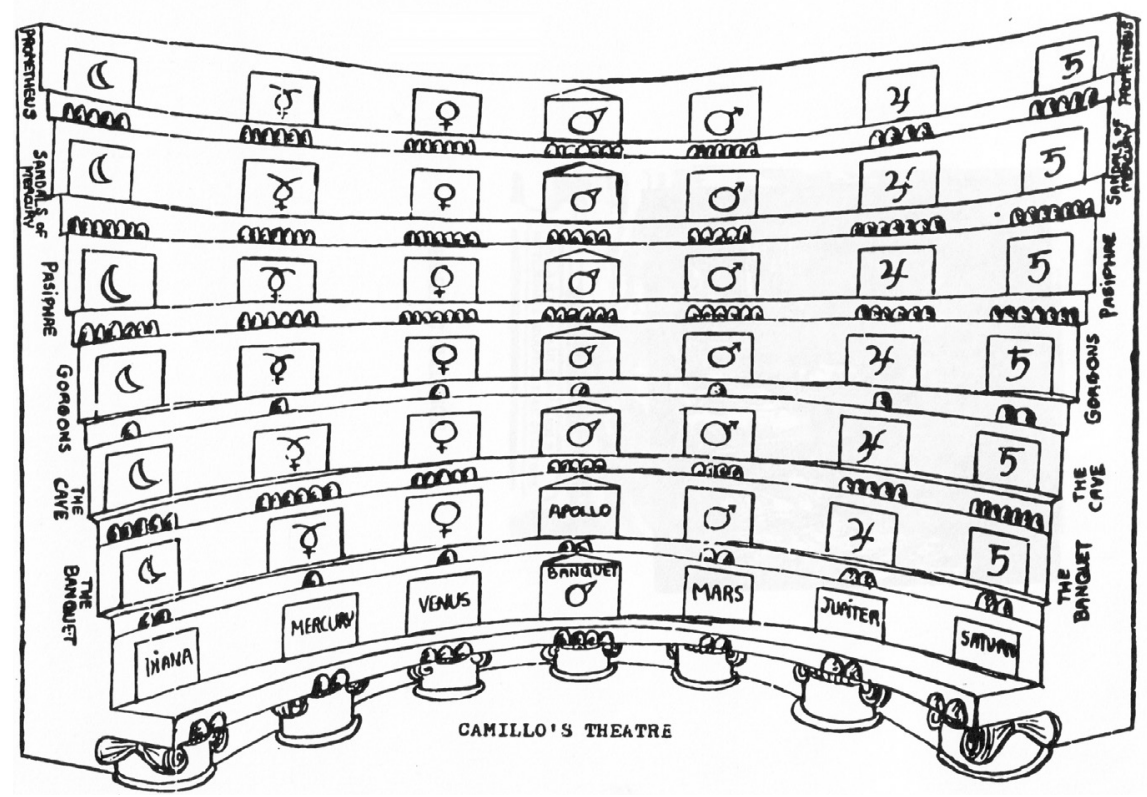

FIGURE 3.2. Sketch of Camillo's Theater (Reconstruction), from Lu Beery Wenneker, "An Examination of L'idea del theatro of Giulio Camillo, Including an Annotated Translation, with Special Attention to His Influence on Emblem Literature and Iconography" (Ann Arbor, MI: UMI Dissertation Services, 1970), 446.

lars of Solomon's House of Wisdom, which hold, according to the holy scriptures, the whole universe. To make them distinguishable, Camillo assigns them to the seven planets of the Aristotelian-Ptolemaic universe: Moon, Mercury, Venus, Sun, Mars, Jupiter, and Saturn. Each of these seven planets rules one of the seven segments of the theater, which describe the levels of the Aristotelian cosmos. The first three represent spheres of the macrocosm. On the lowest level (where the highestranking people used to sit in the Roman theater) reside the planets themselves-as the spiritual foundations of creation. On the second level we find the basic elements of creation, the materia prima, represented by the mythological image of the divine banquet of Oceanos, after Homer's tale. On the third level Camillo places the mixed elements, that is to say, nature, illustrated by the Homeric cave of the nymphs. The fourth level transitions from the macrocosm of creation to the microcosm of man, beginning with the most spiritual aspect-his inner being, his mind and soul. Camillo marks this by an image of the Graeae, the three sisters of the Gorgons who pass a single eye between them in order to see, which he interprets as an indication of the extent to which the "divine ray" of human understanding is external to the self. (Camillo here mistakenly calls these three hags le Gorgoni-an error perpetuated by Yates in her reference to this passage. ${ }^{23}$ On the fifth level we find the human body, depicted by Pasíphaë with the bull. The sixth 


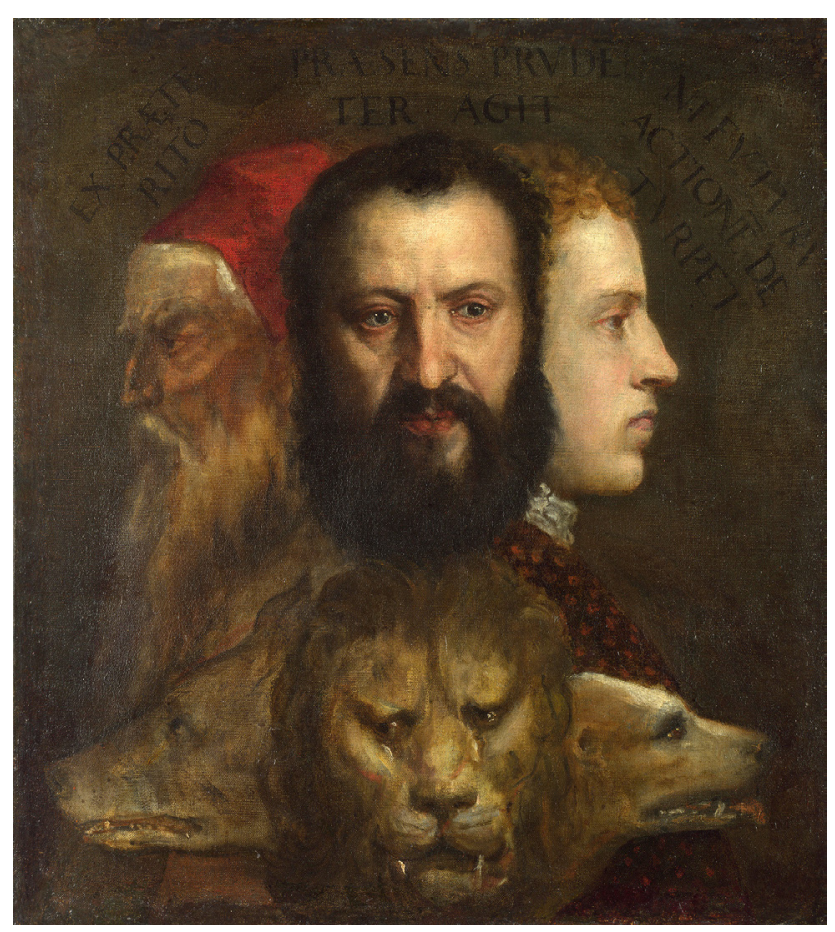

FIGURE 3.3. Titian, Allegory of Time Governed by Prudence, ca. 1550, oil on canvas, 75.4 X $173.74 \mathrm{~cm}$ (29 3/5" x 68 2/5"). London, National Gallery. https://commons.wikimedia.org/wiki/ File:Titian_-_Allegorie_der_Zeit.jpg

level is reserved for activities connected to biological self-preservation, showing Mercury putting on his sandals. The seventh level, finally, represents man's productive activities-from the crafts through the fine arts to science, represented by an image of Prometheus with a burning lamp.

The images mentioned thus far depict the architectural structure of the theater, like seat tags-albeit ones giving the seating order of the whole cosmos. On the seats themselves, Camillo again places images, at times more than one per seat. In total, his treatise names more than two hundred images, some of which are repeated on different seats. Most of these images can be traced back to the iconographical tradition. ${ }^{24}$ For the purposes of this article, I will confine myself to a single prominent example to explain how these images are used (figure. 3.3).

At three of the loci of his theater, Camillo places an image described as "three heads of a wolf, a lion and a dog." This description closely matches Titian's famous Allegory of Time, which depicts the heads of the same three animals beneath the heads, respectively, of an old man, a man in his prime, and a youth. As Erwin Panofsky and Fritz Saxl have shown in their discussion of this work, the depiction 
of Prudence as having three heads - namely those of a wolf, a lion, and a dogwas commonly known in the artistic circles of Venice in which both Titian and Camillo moved and is rooted in an old iconographic tradition that can be traced back to Egyptian Hellenism. ${ }^{25}$ Titian is believed to have fully illustrated an edition of Lidea del theatro (see note 8). Although that volume is now lost, the Allegory of Prudence, painted about fifteen years after the publication of Camillo's treatise, can still offer a unique glimpse of what the images of his theater might have looked like. Given Titian's close acquaintance with Camillo and his project, there can be little doubt that Titian's painting aligns with what Camillo had in mind.

In the background of the painting, a Latin inscription associates the pairing of the old man and the wolf with the past; the middle-aged man and the lion with the present; and the young man and the dog with the future. It reads: "[F]rom the past / the present acts prudently / lest it spoil future action." The image therefore engages with the phenomenon of time and how it is to be wisely used. Other images in Camillo's theater also thematize time, but they are assigned to sections ruled by other planets and therefore represent different aspects of it. For example, the image of Diana in the Moon sector stands for the months and their parts and the picture of Geryon in the Sun's sector, for the seasons. These optimistic meanings of time as reproductive cycles of recurring intervals differ from the meanings in the Saturn section. The planet Saturn is, according to the astrological tradition, linked to melancholy. In its sector, then, the Allegory of Time is seen from a pessimistic perspective as ephemerality. And this general significance again varies in the three instances the allegory is used in the theater depending on the level at which the image is placed. With regard to the instance on the cave level (which represents the macrocosmic level of nature in its basic form of mixed elements), Camillo writes:

The three heads of the wolf, lion and dog are so, Macrobius writes, ${ }^{26}$ since the ancients, wishing to illustrate the three times, that is, the past, present and future, depicted the abovementioned three heads. That of the wolf signified time past, because he has already devoured it. That of the lion is the present (if one can give the present), because present troubles thus encountered, strike terror in us, which the face of a lion would do, if it overcame us. That of the dog indicates future time, because in the manner of a fawning dog, the future always promises us something better. (46)

The perspective corresponding to the cave level thus takes the fleeting nature of time as its objective natural condition. "The same image of the three-heads under Pasiphaë," however, Camillo writes, "shall indicate man being subject to time" (47). For at the Pasiphaë level, we are in the microcosmic sphere of the human body, which, from the perspective of Saturn, is perceived in its physical transience. At the level of Mercury's sandals, finally, which represents human activities connected to biological self-preservation, the same image in turn becomes an emblem for the attempts to stop time or to escape it by breaking off an activity and seeking 
a new one, as Camillo notes in shorthand fashion: "The three animal heads, delaying, causing delay, to put an end to, to put off to another time" (78).

What we have seen here is merely a small set of the permutations of possible meanings of the images, which should suffice to suggest the tremendous range of combinational dynamics enabled by Camillo's theater-assuming that the visitor will implement them to full effect in his imagination. The example demonstrates how Camillo embedded the classical images agentes into an ordo agens, creating emblems that change their meaning in relation to where they are situated within the theater. This transformation of the traditional memory palaces of the ars memoria into a playhouse of the entire cosmos, made dynamic by the Lullistic ars combinatoria and illustrated with emblematic picture puzzles, had a mixed reception among Camillo's contemporaries. To his devotees from Venetian artistic and hermetic circles, his device appeared to be an innovative path to universal knowledge. From the perspective of his Humanist critics, however, it undermined the idea of an efficient encyclopedia, since the emblematic character of the images had to be interpreted in a complex process of deciphering. They found the approach retrogressive and saw the future of knowledge instead in printed "theater" books. Indeed, if Camillo's primary and fundamental concern had been to design a universal scientific storage device, it remains incomprehensible why he encoded it in such a manneristic way. How, then, did it come to pass that the very distant future of the Information Age would take up Camillo's "visions, which inspire but do not inform"(8)?

\section{CAMILLO'S COMEBACK WITH THE AID OF YATES}

Camillo's theater project was all but forgotten when Frances Yates was handed the treatise by Ernst Gombrich in 1950. Although several other publications during the 1950 s and up to 1960 had mentioned Camillo, ${ }^{27}$ it was not until the great success of Yates's 1966 book, The Art of Memory, that he became known to a wider audience. But Yates did not enable Camillo's comeback by adapting the representation of his system of memory to the reception horizon of the dawning computer age. Quite the contrary. She emphasized the very aspects that stood in contrast to the technical rationality of the modern organization of knowledge. Her particular achievement consisted precisely in elaborating the hermetic foundations on which Camillo's theater conception was built. This required extensive research. Five years after she began, she gave the first lecture on Camillo at the Warburg Institute, in which she presented a plan of his theater, placing in it the names of the more than two hundred images mentioned in the treatise. ${ }^{28}$ The images and even the cryptic explanations of them that Camillo offered remained for her largely puzzling, but nonetheless she perceived "that there was some historical connection between Camillo's Theatre, Bruno's and Campanella's systems, and Robert Fludd's Theatre system" ${ }^{29}$ - works that did not fit in with the generally encyclopedic tendencies of the Theatrum literature mentioned above. "Why," she wondered, "when the inven- 
tion of printing seemed to have made the great Gothic artificial memories of the Middle Ages no longer necessary, was there this recrudescence of the interest in the art of memory in the strange forms in which we find it in the Renaissance systems of Camillo, Bruno, and Fludd?" ${ }^{\circ}$ She assumed "that the stimulus behind Renaissance occult memory was the Renaissance Hermetic tradition" and that she would have to write a book on that tradition before she could come to explain Camillo's theater within its historical context. She therefore wrote Giordano Bruno and the Hermetic Tradition ${ }^{31}$ as an extensive preface to the Renaissance chapters of The Art of Memory. Here, she worked out, among other things, the influence exerted on the Venetian Renaissance by Marsilio Ficino's translation of the Corpus Hermeticum, completed in 1463, as well as the writings of Pico della Mirandola, who was born that same year. She saw this influence particularly strongly in Camillo, whose L'idea del theatro was, according to Yates, "full of echoes"32 of Pico's Oration on the Dignity of Man. ${ }^{33}$ Moreover, she thought it possible that a passage in the latter text, in which Pico mentions a "theatre of the world (mundana scaena)" 34 and relates it to a saying of Mercurius Trismegistus, may have served as the inspirational source for Camillo's Idea. ${ }^{35}$

The significant point in Yates's argument, which we take up in detail here, lies in this: It was precisely in the turning back to Hermeticism (believed at the time to be rooted in the archaic wisdom of Egypt) that she perceived the decisive source of a new self-conception of the human being as an autonomous subject, which had first enabled the future progress in science and technology to begin with. In this way, she stood on its head the traditional narrative of the process of rationalization that leads from Renaissance Humanism to modernity. With regard to the competing positions in the above-mentioned Ciceronius debate, she determines that the disparaging remarks made by Erasmus and Viglius about Camillo's theater were grounded in a false assumption:

For the Erasmian type of humanist the art of memory was dying out, killed by the printed book, unfashionable because of its mediaeval associations, a cumbrous art which modern educators are dropping. It was in the occult tradition that the art of memory was taken up again, expanded into new forms, infused with a new life. The rational reader, if he is interested in the history of ideas, must be willing to hear about all ideas which in their time have been potent to move men. The basic changes of orientation within the psyche which are shown to us by Camillo's memory system have vital connections with changes of outlook out of which new movements were to come. The Hermetic impulse towards the world and its workings is a factor in turning men's minds towards science. Camillo is nearer than Erasmus to the scientific movements, still veiled in magic, which are stirring obscurely in the Venetian academies. ${ }^{36}$

Yates's perspective on the history of media and ideas, which was absolutely exceptional and downright "adventurous" ${ }^{37}$ for her time, at first garnered sharp criticism from her colleagues. In 1974, they convened a conference on the "Yates 
thesis" to counter the "vogue for Hermeticism" that Yates had called into being with her "overly enthusiastic results" about the influence of occult thinking on the scientists of the Renaissance. ${ }^{38}$ The assessment of the Bacon expert Brian Vickers was even harsher. In 1979, he wrote in an article in the Journal of Modern History: "Yates's proposed rewriting of Renaissance history is an edifice built not on rock nor on sand but on air." ${ }^{39}$ With "the infectious energy of her style," she would create a "rhetoric of excitement which will take many readers along with it." 40

The latter was definitely true. Even as criticism from scholars continued, ${ }^{41}$ artists, in particular, felt rather drawn in by Yates's vivid style of writing, which J. B. Trapp characterized as follows: "Entering the past through an intense imaginative effort and in a sympathetic spirit, she recreated its intellectual life by insights and arguments that upset accepted ways of thinking and opened or reopened many doors that had been judged either not to exist or to have been sealed for good." ${ }^{2}$

Although Yates had emphasized the connection between Camillo and the classical memoria tradition-and coined the term "memory theater" 43 that was never used in Camillo's writings (he called it Il theatro della sapientia ${ }^{44}$ )-her vivid description made clear that the main purpose of his ordo was not just to learn things by heart, but to "jog the memory," thereby activating the imagination of the visitor. To express it in rhetorical terms: It was neither the dispositio, the arrangement of subject matters, nor the memoria, but rather the inventio-the creation of ideas-that was Camillo's main concern..$^{45}$ Again and again the treatise focuses on the words "creation" (e.g. 10), "generation" (e.g. 18), and "production" (e.g. 17). And this inventive aspect was best and primarily understood by artists.

The exhibition organizer Harald Szeemann was one of the first who stepped gratefully through the doors, in contrast to Yates's academic colleagues. In 1975, while drafting his concept for the contemporary art exhibition Documenta, which takes place every five years in Kassel, Germany, he wrote:

The core of the plan is the Prototype of the Museum of Obsessions. In its outer form, it follows the Theater of Memory of the Venetian Giulio Camillo (1480-1544), a complex visualization of the systems of memory. . . . The auditorium is thus turned into a scene that the beholder observes from the stage. The entire thing is a Gesamtkunstwerk into which Camillo has incorporated all the artists, all the knowledge, all the memory images offered by the analogical thinking of the Renaissance. This reversal of theater finds its correlate in the demand for participation in contemporary art. Marcel Duchamp's call for an eyewitness who would complete the image through the temporal act of beholding proceeds from the same premises; and his main work, which can only be read through seeing and understanding "the decoding of his notes in the Green Valise". . . is the hermetic correlate of our time to Camillo's hermetic-alchemical Theater of Memory. ${ }^{46}$

It can also most certainly be traced back to the influence of Yates that the same year the French painter and sculptor Jean Dubuffet titled one of his series Théâtres de mémoire, "which is composed of vast canvases, each created with smaller scenes 
and segments to illustrate the abstract and jumbled landscapes that characterize the memory." 47

In 1993, the Danish artist Mikael Thejll created an installation titled Anatomical Theater and Memory Theater, which made exhibition itself into an object of critical reflection by presenting a plaster sculpture of a corpse in the style of eighteenthcentury anatomical theater against the backdrop of a stylized rendition of Camillo's amphitheater as portrayed by Wenneker (figure 3.2). The installation, shown as part of an exhibition about Wunderkammern (cabinets of curiosities) ${ }^{48}$ thus problematized the mortifying nature of museum exhibitions and at the same time elevated it by making it the object of reflection in itself.

Two other, more recent exhibition concepts that were likewise inspired by Camillo via Yates are THE MUSEUM OF ME (MoMe), ${ }^{49}$ from 2009, by Canadian artist Heidi Ellis Overhill, and Eikoh Hosoe: Theatre of Memory, held at the Art Gallery of New South Wales in 2011, presenting the works of the Japanese photographer Hosoe. ${ }^{50}$ This reception strand is supported by Yates's view on Camillo, given that she drew associative links between historical configurations to evoke their afterlife-a procedure that certainly was influenced by her acquaintance with Aby Warburg's Mnemosyne project. ${ }^{51}$

While these exhibition concepts aim to turn space into the experience of time, another reception strand follows the converse direction within the time-based arts of literature and music, which are then turned into spaces for memorization. In a chapter of his novel Terra nostra (1975), Mexican writer Carlos Fuentes introduces fictional Valerio Camillo, who is working on a memory theater..$^{52}$ The description conspicuously follows that of Yates, but in Fuentes's novel-which is modeled after James Joyce-Valerio Camillo plans a theater of the complete history of the world, including all possible events that could have happened. The novel thus provides " $\mathrm{a}$ poetologic model of how it should be read." ${ }_{33}$

It is interesting that poetry as a time-based art could draw inspiration from Camillo's architecture, but it is even more striking that music also did so. John Buller, who initially worked as an architectural surveyor, developed under the influence of Ralph Vaughan Williams and Harrison Birtwistle into an appreciated composer of new music. His symphonic work The Theatre of Memory, composed for the 1981 BBC Proms and "dedicated to the memory of the late Francis [sic!] Yates," 54 arranged the ninety orchestral musicians, in exact accordance with Camillo's theater, in a "semicircle of seven rising tiers and wedges of players" so that-as Camillo intendedthe audience members in the auditorium would have the impression of "looking from the stage" ${ }^{\prime 55}$ so that they feel similarly stimulated to follow their own trains of recollections while listening to the music. In an analogy to the seven ruling planets of the Theatro, Buller placed seven soloists in the front row: celesta, flute, cello, English horn, trumpet, harp, and contrabass clarinet. "Behind these," he explains, "the orchestra is re-ordered in families so that the memory process spreads naturally according to function, as in Camillo's theater. Sometimes these wedges are used in 
sticomythia or line-by-line talk, sometimes the cross-rows are used (particularly in the fourth episode, where they form chords)." ${ }^{66}$ Thus, time becomes space. ${ }^{57}$

In 1993, the Dutch theatermaker Riek Swarte staged Camillo's Theatro in a production titled The Theatre of Memory or the Mystery of the Lost Secret. "The team did extensive research into the history of the Ars Memoria, made their own reconstruction of Camillo's memory theater, trained themselves in mnemonic techniques and even used part of their project funding to take a trip to Venice where they studied Camillo's treatise L'idea del theatro (1550) in appropriate surroundings." ${ }^{8}$ Camillo's theater was reconstructed for the performance in wood. Inside, the audience was instructed to learn a poem by Jorge Luis Borges by heart with the help of the Theatro, and the method turned out to be astonishingly useful for the purpose. This experience was contrasted with the loss of memory through external storage, from the printed book to data banks.

The poet and professor of Spanish Carlota Caulfield named one of her volumes of verse The Book of Giulio Camillo: A Model for a Theater of Memory (2003), also with the intention of constructing a mental space. In her preface, she states that in her view Camillo "offered the possibility of discovering all of the corners of the human soul and of reaching the inmost depths of the mind." 59 To achieve the same with her poems, she arranges stanzas in seven sections of seven. Each of the stanzas consists of three verses, of which the first always expresses an idea or an image that is expanded upon in the following two lines. It is left to the combinatorial imagination of the reader to decipher the deeper meanings of the tercets.

The novel Memory Theatre (2014) by the English philosopher Simon Critchley is rather conventionally written, but with a plot that sheds new light on Camillo. ${ }^{60}$ The protagonist (who has much in common with the intellectual biography of the author) one day receives a parcel, anonymously sent, containing a maquette of Camillo's theater. He rereads his copy of Yates's Art of Memory and wonders: "Was this the original model that Camillo had used to persuade the King of France to become his patron?" Fascinated by the piece, he decides to construct a life-size theater of memory based on the maquette. His understanding of Camillo's ideas is influenced by an essay by his friend Michel, who reads Hegel's Phenomenology of Spirit as a theater of memory, underscoring Hegel's memory concept as one based on the German word "Erinnerung," which "denotes both recollection and the active experience of making inward." ${ }^{11}$ As such, it can be opposed to forms of external, mechanical, technologized, or even neuro-physiological memory, captured in the word Gedächtnis. "The Hegelian art of memory is the inwardizing of all the shapes of Spirit." ${ }^{2}$ Therefore, by reconstructing Camillo's theater, the protagonist seeks to become one with Hegel's absolute spirit through inwardizing all the experiences of his life, arranged in ontological spheres on the seven levels, each segmented in thematic groups, and all represented by statues as reminders, with wooden drawers underneath for papers, records, and photographs that were related to them. 
I sat there for hours running through the loci and rehearsing the meanings of the various statues until I recalled everything lucidly. Time had become space. History was geography. Everything was a map and I'd mapped everything. I'd built a vast, living, personal encyclopedia or living intelligence system, where, through mnemotechnics, I would be given a conspectus of the whole. This was the way I would finally overcome my amnesia. Total recall. Lights out. ${ }^{63}$

But nothing happens. In the end, he realizes that he had totally mistaken the concept:

The grotesque scale of the error I had made gradually became clearer to me. What I had built in my Dutch backyard was a flat literalization of the idea of the memory theatre. It was a sort of static, inert, dead rendering of an entity that had to be multidimensional, mobile and somehow alive. ${ }^{64}$

He therefore decides to start from scratch and

create something permanently moving. A wheel that turns, returns, and turns again. Hegel's memory theater was a kind of perpetuum mobile, a permanently recreating and re-enacting loop. Knowledge of the Absolute, achieved through recollection, was a vast living organism, a totality endlessly creating novelty out of itself. ${ }^{65}$

And his plan points toward using new media for that purpose:

This would not be another, static memory theatre, but a living machine whose power would be generated by the constant ebb and flow of tides. Moon powered. I began to make little drawings in crayon for a kind of cinematic projection system. I needed to find visual, moving analogues to the entirety of world history that could be projected onto a specially prepared landscape. ${ }^{66}$

Thus, it would be not only a machine for memorizing the past but at the same time a "predictive machine." ${ }^{67}$

In the course of his self-experimentation, the protagonist might have gained some wisdom, but at the same time he goes mad. Here the author seems to play upon Yates's view of the Renaissance theater system:

This madness had a very complex method in it, and what was its object? To arrive at universal knowledge through combining significant images of reality. Always we had the sense that there was a fierce scientific impulse in those efforts, a striving, on the Hermetic plane, after some method of the future, half-glimpsed, half dreamed of, prophetically foreshadowed in those infinitely intricate groupings after a calculus of memory images, after arrangements of memory orders in which the Lullian principle of movement should somehow be combined with a magicized mnemonics using characters of reality ${ }^{68}$

It was precisely this "scientific impulse" to find "some method of the future" that was seized upon during the second strain of the book's reception, to which we now turn. 


\section{IMAGINING THE FUTURE OF HCI THROUGH}

\section{REMEMBERING CAMILLO}

To understand why it was the modern computer age, of all times, that created a favorable climate for Camillo's reception, we must recognize that both are characterized by a turn away from the culture of the book. Just as in the early era of the printed book Camillo turned away from its humanistic protagonists and, seemingly anachronistically, toward pictorial memory, so in its end phase did digitalization now create a "cultural dispositif for visuality, new media, and postmodern narrativity" that, in Barbara Keller-Dall'Asta's words, established this "fascination through Camillo in the waning 2oth century." ${ }^{69}$ Indeed, Marshall McLuhan's The Gutenberg Galaxy is already a swan song to the era of the printed book, which brought with it a linearization of thinking and a narrowing down of an earlier multimediality to a normed typography.$^{70}$ At the time that Yates published The Art of Memory, however, this cultural capacity was still in its infancy. In 1966 computers were first and foremost calculating machines-which explains why, as mentioned above, Yates only referenced the "mind machine analogy" in relation to the "permutations and combinations of the changing relations" in Bruno's Lullism ${ }^{71}$ and not to Camillo's theater. In this early phase, human-computer interfaces depended on punch card readers or keyboards for input and line printers as primary output devices; their cognitive concepts were based on "an amalgam of engineering and human factors," which "saw interaction as a form of man-machine coupling in ways inspired by industrial engineering and ergonomics." ${ }^{72}$

Of course, there were already fantasies about machines of the future that would be able to combine images on displays. The most prominent of these, which turned out to be the most influential for technological development, was Vannevar Bush's concept of Memex (the abbreviation alludes to the function of "extending" one's memory), published in $1945 .{ }^{73}$ Bush's essay was an important source of inspiration for Ivan Sutherland and Douglas Engelbart, who considerably advanced the development of computer displays and pointing devices. But it was not until the mid-1980s that a new HCI paradigm could establish itself.

Yates's book, however, had already begun to gain attention in technically inclined circles-at first, again, among artists. At Syracuse University in New York, media artist Robert Edgar recalls receiving the book from his friend Robert Polidori, a Canadian photographer, in the early 1970 . ${ }^{74}$ Edgar in turn shared it with his classmate Bill Viola, with whom he was working in the Synapse video collective. Both would later pioneer the renaissance of Camillo in cyberspace, once computers had the necessary graphical user interface.

Yet Yates's book seems already to have offered important inspiration for a new HCI paradigm to come. In the mid-1970s MIT formed a working group to research "Augmentation of Human Resources in Command and Control through Multiple Media Man-Machine Interaction."75 The results were published in 1976 by Richard A. Bolt under the title Spatial Data Management. There, he writes: "Intrinsic to the 


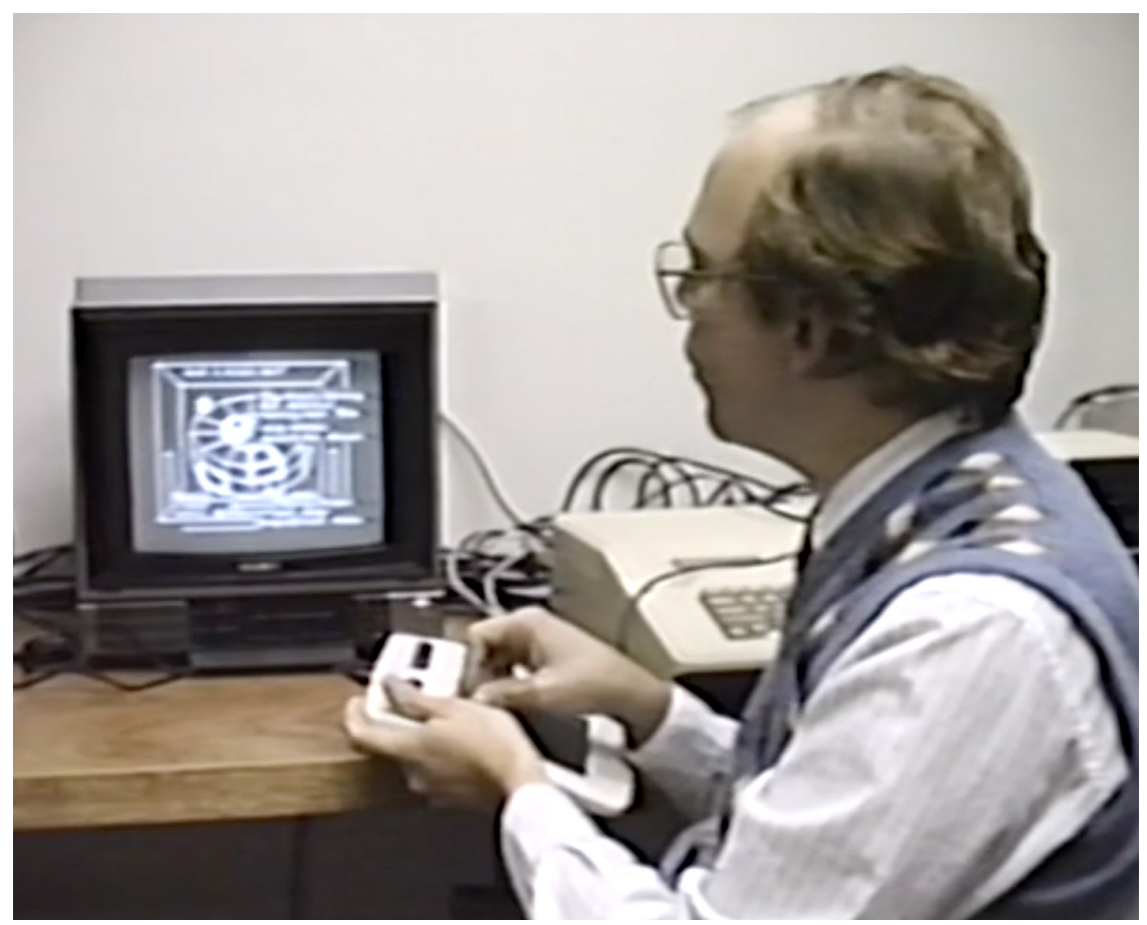

FIGURE 3.4. Robert Edgar presenting his Memory Theatre One (1985), film still, 1986. https:// vimeo.com/33134008.

ensemble of studies outlined in the proposal was a study recalling the ancient principle of using spatial cueing as an aid to performance and memory: the 'Simonides Effect." ${ }^{76}$ What follows is an extensive presentation of classical loci methods-with some philological errors that make it evident that the original sources were not consulted and with wording that reveals Yates as the secondary source. ${ }^{77}$ With their spatial HCI concept, the MIT researchers paved the way for corresponding developments that were further advanced at Xerox PARC and ultimately led to the Apple Macintosh in 1984.

Even earlier, the Apple II was already equipped with rudimentary graphic capabilities that could be controlled with pointing devices. While the MS-DOS that came with the first PC still forced the user to learn long lists of alphanumeric keyboard commands, the Apple II was already equipped with so-called paddles that moved a cursor with two wheels that the user had to turn for horizontal and vertical positioning. And this was the moment at which media artist Robert Edgar could realize his Memory Theatre One, an interactive 3-D computer program, released on an Apple II computer, and programmed in GraForth, with a "Koala Pad," an early precursor of the touch screen, as a steering device (figure 3.4). This was the very first attempt to realize with digital means what Camillo had left to the future to explore. 
Edgar's project incorporates some elements of Renaissance cosmology, but at the same time it is driven by the question: "What, I wondered, would an art of memory be like today, when no cosmology can summarize even a single text?"78

Edgar's artistic answer, the virtual architecture of his 3-D model, consists of a rotunda with two side rooms: a library and an additional memory room containing the zodiac. These two side rooms represent, as it were, the two poles between which Camillo operated-the encyclopedism of the dawning age of printing and the magic of the Hermetic tradition-to generate a new technique of invention out of the tension between them. Analogously, Edgar attempts the transition from the Gutenberg to the Turing galaxy for our own time. The central piece of Memory Theatre One shows two levels with twelve memory rooms each. The upper circle is referred to as a "microcosm," in which we find combinations of images and autobiographical notes that offer the visitor dynamic loci for reflection. The lower circle stands for the "macrocosm," in which Edgar has put two pedestals in each room: each pedestal holds an icon, along with a compilation of quotations from newspapers and books. Each of the lower rooms is paired with a room above.

Thus, Edgar does not transfer the historic memory theater model naively one to one, but rather reproduces its inventive momentum in the self-referential context of today's information technology: The visitors find themselves in an intermedial space between image and text, a space of intertextuality and interpictoriality in which one literally reads between the lines of words and pictures, thereby filling the semantic gaps with one's own cognition and imagination. That same year, in 1985, Bill Viola created his video installation Theatre of Memory, consisting of an uprooted tree with its branches festooned with flickering lights, and a projection of a static-filled video image. ${ }^{79}$ Though it appears to be a classical work of video art, it is a thorough reflection on the digital age, as can be inferred from his 1982 article "Will There Be Condominiums in Data Space?"80

Edgar and Viola are thus forerunners of a new, cognition-oriented HCI paradigm, which became available with the Apple Macintosh in 1984 and Microsoft Windows in 1985. This new HCI paradigm followed a cognitive psychological model that was "organized around a central metaphor of mind and computer as symmetric, coupled information processors." ${ }^{11}$ Instead of communicating with the machine through typed commands that had to follow its algorithmic structure, the user now had icons at hand that were intuitively graspable and thus functioned as "boundary objects" ${ }_{2}$ between the computer's cryptic operations and the user's ways of perceiving and thinking. ${ }^{83}$

Once the perception of computers changed-to devices that could model mind processes rather than mere calculating machines-Camillo's Theatro could be seen as an important milestone in the prehistory of the neurosciences. As part of an exhibition on that prehistory in Florence in 1989, the art historian and Camillo 
expert Lina Bolzoni curated a 3D model of the Theatro. In her opening article for the exhibition catalogue, she described Camillo as a "cabbalist programmer" and his theater as an "ultimate computer." ${ }_{4}$

During the 1990s, Mac and Windows computers became ordinary work tools for humanities scholars. Apple's Hypercard, a database development tool with a graphical, user-modifiable interface, released in 1987, allowed many users with no previous programming experience to create their own applications. Among these was a Theatre of Memory by Graham Howard and Rob Bevan (1991), which used Camillo's architecture as a user interface for an introduction into the work and time of Shakespeare. ${ }^{85}$ With the increasing ability to access the World Wide Web developed by Tim Berners-Lee at CERN, just outside Geneva, Switzerland, certain parallels between the data universe that had newly become populated with images and the ars memoria tradition came into focus for Renaissance scholars. Participants from the United Kingdom and the United States attended a symposium at the University of St. Andrews in 1998. The presentations were published two years later under the title The Renaissance Computer. In her contribution to the book, Leah S. Marcus devoted herself to a comparison of Camillo's Theatro and the graphical user interfaces of the time. She writes: "Just as in classical and Renaissance memory schemes, the computer allows us to imagine the localities of memory operation, with systems of files, folders, and websites fulfilling the earlier role assigned to an imaginary mental edifice." ${ }^{\text {} 6}$ She does add that the normal Windows icons and the icons used by Camillo are not truly analogous because they are lacking "that degree of energized life and impact." However, she continues, "the World Wide Web does offer many examples of animate figures that resemble traditional memory icons in terms of their uncanny power to stay with us; and the web sites where they are to be found, we can speculate, are more likely to be remembered and revisited." ${ }^{87}$ And she concludes with the conjecture that the highly theatrical and auditory ways of relating to previous scholarship have become possible once more. ${ }^{88}$

Indeed, throughout the 1990s, theatricality increasingly became a guiding metaphor for scientific modeling-which was not unconnected to the development of computer technology. In 1991, Brenda Laurel, a game designer at Atari and Actrivision and later a consultant for video game companies, published her influential book Computers as Theater. ${ }^{89}$ And the fact that in this decade cognitive psychology and neuropsychology increasingly made use of theater metaphors can also be linked to an altered view of computers, which had previously offered researchers of memory in cognitive psychology a common functional model as devices for storage and retrieval..$^{\circ}$ In the humanities, as well, the paradigm of theatricality increasingly prevailed over that of textuality; ${ }^{91}$ after the linguistic turn and in an extension of the pictorial turn, a new performative turn ${ }^{92}$ had been called into being. How should a human-computer interface be designed to do justice to the paradigm of performativity? 


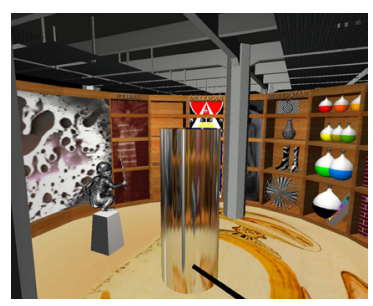

FIGURE 3.5. Agnes Hegedüs, Memory Theater VR, 1997, archive of the artist.

An idea of this was conveyed once more by a media arts project inspired by reading Yates: the installation Memory Theater VR by Agnes Hegedüs, commissioned by the ZKM Center for Art and Media, in Karlsruhe in 1997 (figure 3.5). It is situated in a wooden rotunda with a diameter of about nine meters, reminiscent of Camillo's construction. Inside the rotunda, a panorama projected onto the walls by a computer can be steered with a $3 \mathrm{D}$ mouse, according to its positioning within a small model of the rotunda. The projections reflect the construction of the wooden rotunda, so that the real space is mirrored in the virtual and vice versa. This prevents visitors from being immersed in the projections, and instead makes them aware of the situation of their steering activities. Thus, unlike common VR scenarios, which absorb their users, the Memory Theater VR empowers them to act self-reflectively like stage directors of their own play on cultural memory. When the mouse is turned, the projection turns around the user; moving the mouse up and down allows the user to virtually "enter" one of four so-called rooms. These rooms deal with the history of virtual reality. Among them is "Fludd's Room," which is designed to resemble a cabinet of curiosities as well as Camillo's memory theater. Using emblematic images, Hegedüs alludes here to early attempts to create virtual realities: from alchemical laboratories, to anamorphotic paintings (Gaudemont), to the artificial rooms of Marcel Duchamp and Bill Seaman. In this way, a transmutative order arises from the constellation of rooms understood by Agnes Hegedüs as an "idiosyncratic history and 'cosmography' of Virtual Reality." 93 Here too, we can observe that the magic and encyclopedic aspects of the memory theater are embedded in an inventive arrangement that appeals to the associations and imagination of the observer: The images provide only fragmentary hints that urge the visitor of the Memory Theater VR to generate associative linkages-thus constructing his or her own history of virtual reality.

The Camillo projects produced by Janez Janša (formerly known as Emil Hrvatin) in the subsequent years are literally conceived as performances. CamilloMemo 1.o. The Construction of Theatre, staged in 1998 at the Piccolo Theater in Milan (Italy), was

driven by the question about how Camillo's Theatre, which assumed the existence and storing of conclusive universal knowledge, could be used as a tool of 
manipulation, control and political appropriation. Criticizing such a totalitarian idea, this project sought to explore instead the interactive possibilities of memory. ... Therefore, an interactive webpage was created alongside, called the Theatre of Future Memory, which was also useful for the theatre performance. ... While online people could imagine and write down their concepts about how the twenty-first century would look, which were then used as scripts for a scene in the theatre performance where the above two controlling positions have been deconstructed..$^{94}$

Another mixed-media performance, Drive in Camillo, realized in 2000 on the main square of Ljubljana, Slovenia, was meant as an attempt to translate Camillo's ideas in the urban environment, with projections on surrounding buildings and a "matrix as a huge, 45-meter-tall spider web, stretched between the high-rises, in which a mountain climber . . links human knowledge with acrobatic stunts."95

Media artists have also attempted re-actualizations of Camillo's ideas in the compact format of the ordinary computer monitor. Examples include a website, the Postmodern Theatre of Memory, by Ron T. Simon (2000), ${ }^{96}$ and a 3D animation, Theatre of Memory, by Kate Robinson (2001), ${ }^{97}$ that provided the basis for a book of commentary and reflection she published in 2006. The book seeks to draw connections between the Cosmology of Giulio Camillo and virtual reality technology. ${ }^{98}$

All these attempts to digitally reanimate Camillo's Theatro do not, of course, claim to be more than artistic explorations of how the next generation of humancomputer interfaces might be imagined. The demand for them, however, is more and more clearly articulated by scientists in that field of research. In the alreadyreferenced conference paper, The Three Paradigms of HCI of 2007, the postulated third paradigm, which is supposed to replace the previous two that were based on the perspectives of engineering and of cognitive science, is described as emerging from a perspective whose "central metaphor is interaction as phenomenologically situated. The goal for interaction is to support situated action in the world, and the questions that arise revolve around how to complement formalized, computational representations and actions with the rich, complex, and messy situations at hand around them." 99

The articles on HCI that have appeared since then have increasingly seized upon the understanding of Camillo conveyed by Yates. This includes architectural theorists such as Mario Fallini, who posits a "conceptual architecture" as a "digital transposition of Giulio Camillo's "Theatre of Memory" and adds this explanation:

The theory mentioned is based on the concept of "magical vision" or an insight able to weave the subtle threads of memory that bind objects, images of objects, events and people in the course of time, revealing the unexpected and sometimes astonishing meanings that beat a human and artistic path.... Therefore, as Camillo's Theatre encloses a plurality of symbols in continuous recombinations coded according to 
internal hierarchies, topics and timelines, it is perhaps possible to rediscover inner images as emblems of our existence, activating a movement of perpetual oscillation that brings the memory to be an instrument of knowledge, in one direction, and to catalyze the creation of new memory, in the reverse motion. ${ }^{100}$

A combination of architectural and virtual environments that operate like theater stages in which users become directors of their own data performances has been attempted in Peter Oldfield's World Memory Theatre (2009). ${ }^{101}$

By 2011, Camillo's ideas had become so prevalent that the time had come for Camillo 2.o: Technology, Memory, Experience-the title of a Performance Studies International conference. In their announcement, the organizers wrote:

Camillo's invention took place as developing printing technology allowed for storage of knowledge and information to move outside the brain. Today the "performative turn" and the developments of Web 2.0 make the restrictions of the archive as memory machine tangible and pay homage to the processual, embodied and (inter)active nature of memory.... Of course, today's storage options are technically quite different, but the problem is similar: We face a complex accumulation of externalized data that are not accessible for vivid recollection. ${ }^{102}$

In his contribution to the conference, William Uricchio, professor of comparative media studies at MIT and professor of comparative media history at Utrecht University in the Netherlands, takes Camillo's theater as a model for future HCI concepts, which he calls "performative navigation" ${ }^{103}$ and envisions as follows:

Location-aware technologies, together with vast databases, combine to generate personalized assemblages of public information, rendering any particular location-like Camillo's theater-a space of performance. Data are selected based on user profile, interest or choice; they coalesce in different configurations depending on user movement; they can, in the case of augmented reality, offer visual overlays, permitting us to transform the appearance of the world that we see through our screens. The wandering subject of the memory palace, lost in their dreams, here gives way to a new kind of spectator, one whose interactions with an elaborate database permit individual combinations of information and associations, but always through a common taxonomy and an intersubjective frame. ${ }^{104}$

One might ask what remains in such future scenarios of Camillo's magic, which Frances Yates had placed at the center of her presentation. But Uricchio has an answer for this, too:

Of course, the Hermetic structure of Camillo's creation seems far removed from the binary logics and science of our era. But here, too, things are changing. . . . The algorithmic is not the Hermetic, but in most cases it remains just as carefully guarded, and with workings just as wondrous. ... The relevance of Camillo's theatre, located on the cusp of the Modern era, grows by the day as we move from the Modern into a new zone of transition. ${ }^{105}$ 
To interpret the magical as obscure and, therefore, mysterious technology is certainly one possible way to approach the phenomenon. Yates had something similar in mind when she compared the fascination with Lullism in the sixteenth century to the contemporary interest in "mind machines." ${ }^{106}$ But the crucial aspect for her was something else, namely that the image would experience an inner self-transformation through the external transformation of the elements. She saw Camillo's contribution to scientific progress precisely in this transformative effect of magical practices, in the creation of a new man:

Renaissance Hermetic man believes that he has divine powers; he can form a magic memory through which he grasps the world, reflecting the divine macrocosm in the microcosm of his divine mens. The magic of celestial proportion flows from his world memory into the magical words of his oratory and poetry, into the perfect proportions of his art and architecture. Something has happened within the psyche, releasing new powers, and the new plan of artificial memory may help us to understand the nature of that inner event. ${ }^{107}$

Indeed, we can see that this transformative aspect of Camillo's magic is also increasingly being taken up by HCI research. The general tendency of the third, phenomenological paradigm to go beyond the merely cognitively conceived notion of usability and toward an all-encompassing user experience ${ }^{108}$ is now driven forward by the experimental development of virtual environments that are supposed to enable embodied navigation. ${ }^{109}$ This type of navigation was linked to Camillo's memory theater in an empirical study at the University of Maryland, where it was called "memory palace," but understood not in the classical sense of the ars memoria as only a mental image, but rather as the "subjective experience of being virtually present in the palace." ${ }^{110}$ The authors determine that: "the sensorimotor contingencies of walking and looking around facilitated by headmounted displays contribute to their higher-order immersion and establishing presence." 111 The study not only concludes that "virtual memory palaces are most effective in eliciting a superior information recall," but also envision that a

future work would be to allow people to build their own virtual memory palaces, manipulate and organize the content on their own, and then ask them to recall that information. If their active participation in the organization of the data in virtual memory palaces makes a meaningful difference, then that could be further useful in designing interaction-based virtual environments that could one day assist in far superior information management and recall tools than those currently available to us. ${ }^{12}$

Conceptions of active users, who organize the content and layout of their digital environments themselves, have long been proposed under the rubric of user-generated content and user-driven design. What is relatively new, however, is the notion of the user as an actor who moves around inside the theater of data arrangements that he or she has built in order to experience combinatorial operations in the flesh. 
Even the magical number seven-which the Harvard psychologist George A. Miller declared in the 1950 s to be the perfect unit of measure for working memor ${ }^{113}$ - is being discussed again in HCI studies after the notion had come under diverse criticism. ${ }^{114}$ And it remains to be seen whether, in relation to this, the "seven measures" of Camillo's theater may also one day be re-actualized in those discussions.

It is evident that Camillo's magic gets lost to the extent that it is operationalized. This, indeed, is also true of Yates's explication of the Theatro. To demonstrate its magic and its significance for the history of ideas, she had to at the same time demystify it, to lift the "veils" under which Camillo sought to preserve his secret. It is thus the irony of history that Yates's rediscovery of Giulio Camillo as a rather peculiar, hidebound, occult opponent of the humanistic process of rationalization - for which she was heavily criticized by positivistic historians-led to Camillo's adaptation as the precursor of the even-stricter rational workings of computer technology.

In the end, it seems magical that Camillo's reliance on a past mnemonic tradition, seemingly made obsolete by the printing press, would extend its influence into the far-distant future of the digital age. The secret of what turns out today to be a backward-looking prophecy is not to be found in its prediction of things to come but in the inventive processes that the Theatro evokes. The arrangement of cultural memory in a way that allows the visitors to be stage directors of their of knowledge perfromances is akin to an alchemical transformation from death to life: It transforms the memory-corpses from the legend of Simonides into vivid recollections; the space-based concept of storage into the time-based one of storytelling; semantic into episodic memories. Therefore, an adequate reception of Camillo's L'idea by present-day research in the field of HCI is not to simulate the Theatro as such, but instead, to invent interfaces that similarly stimulate the inventive mind. 